\title{
Early and Late Onset Preeclamsia: What did really Matter?
}

\author{
Sri Sulistyowati* \\ Department of Obstetrics \& Gynecology, Faculty of Medicine Universitas Sebelas Maret. Dr. Moewardi General Hospital Surakarta, , Indonesia
}

Submission: June 05, 2017; Published: June 27, 2017

*Corresponding author: Sri Sulistyowati, Faculty of Medicine Universitas Sebelas Maret. Dr. Moewardi General Hospital Surakarta, , Indonesia,

Email: elis_spog@yahoo.co.id

\section{Summary}

Preeclampsia is main cause of morbidity and mortality both mother and fetus. Preeclampsia occurs in 2-10\% of pregnancy and that was no changed during the last century. Endothelial dysfunction was believed as cause of preeclampsia incidence until now their mechanism is unknown. Preeclampsia was divided in two kind of preeclampsia, early onset preeclampsia is occur at less $<34$ weeks of gestation age and late onset preeclampsia is occur at $>34$ weeks of gestation age. Early and late onset preeclampsia have different etiologic and should be considered as different diseases then there are difference in the term of marker, clinical manifestation, maternal and perinatal outcome, prognosis, and complication. Early onset preeclampsia has a much worse maternal and fetal outcome than late onset preeclampsia

\section{Text}

Preeclampsia is a pregnancy associated with hypertensive disease that occurs after 20 weeks' gestation. Preeclampsia is still a major contributor to maternal and fetal morbidity and mortality [1]. The incidence of preeclampsia is 2 to $10 \%$ of all pregnancies in the world. According to WHO the incidence is 7 times greater in developing countries compared to developed countries [2]. Preeclampsia cases in Indonesia causing 30$40 \%$ of maternal death and $30-50 \%$ of perinatal death. In Dr. Moewardi General Hospital Surakarta Indonesia maternal mortality which were caused by preeclampsia were 19 ot of 30 maternal mortality cases and increasing to 12 out of 21 in 2013 [3]. Preeclampsia is distinguished into two: early onset where preeclampsia occurs at $<34$ weeks' gestational age and late onset occurring at $>34$ weeks of gestation. The early-onset concept of preeclampsia and late-onset of preeclampsia is more modern, and it is widely accepted that these two entities have different etiologies and should be regarded as different forms of disease [4].

\section{The difference between early and late onset preeclampsia}

Early onset and late onset preeclampia have different implications for fetuses and neonates, with perinatal mortality rising about 10 -fold higher on early onset, and doubling in late-onset. Early onset preeclampsia is a severe pregnancy complication characterized by elevated blood pressure, metabolic and inflammatory changes leading to generalized endothelial dysfunction and end-organ damage due to vascular disorders. Early onset preeclampsia is a potentially life-threatening disease for both mother and baby [5]. Early onset preeclampsia is the most severe clinical variant of disease occurring 5-20\% of all cases of preeclampsia and is associated with impaired fetal growth, fetal pathology and uterine blood circulation, small size of the placenta, preterm delivery, neonatal morbidity and mortality. Early onset preeclampsia developments are associated with impaired trophoblast invasion, complete transformation of the uterine spiral artery, immune maladaptation and increased markers of endothelial dysfunction. Preeclampsia late onset is about $75-80 \%$ of all cases of preeclampsia; Which are associated with maternal morbidity (metabolic syndrome, impaired glucose tolerance, obesity, dyslipidemia, chronic hypertension), normal birth weight and normal placental volume [6].

\section{Risk Factors}

There are differences in risk factors between early-onset and late-onset preeclampsia, a history of chronic hypertension and family history of hypertension. The history of chronic hypertension was significantly associated with an increased risk of early onset onset of preeclampsia, whereas a history of chronic family hypertension was significantly associated with an increased risk of late-onset preeclampsia alone [7]. Early onset preeclampsia predictors are African race, chronic hypertension, previous preeclampsia history and ovulation drug use. Predictors 
of late-onset preeclampsia and gestational hypertension increase with maternal age and BMI, and family history or preeclampsia history. The rate of early detection of preeclampsia, late-onset preeclampsia and gestational hypertension in screening with maternal factors was only $37.0 ; 28.9$ and $20.7 \%$, respectively, to a false positive rate of $5 \%$. History of preeclampsia or eclampsia in previous pregnancies, passive smoking exposure, inadequate antenatal supervision, family hypertension history in one or more first-degree families, living in a shared family, overweight and lower socioeconomic status were associated with increased risk early onset of preeclampsia and eclampsia [8]. Obesity and obesity increase the risk of preeclampsia, which is explained by elevated levels of fatty acid triglycerides and free fatty acids. These lipid changes may produce a major factor causing endothelial cell dysfunction in preeclampsia with increased circulating levels of lipid peroxide oxidative stress. This can cause endothelial cell damage [9]. Maternal weight $<0.2 \mathrm{~kg}$ per week is a significant protective factor for the onset of preeclampsia. Pre pregnancy BMI $<20 \mathrm{~kg} / \mathrm{m}^{2}$ is a significant protective factor for late onset preeclampsia. The history of chronic hypertension is a significant risk factor for early onset preeclampsia. A family history of chronic hypertension is a significant risk factor for late onset preeclampsia. Chronic hypertension can lead to endorgan damage and complications of blood vessels. This may be the reason why chronic hypertension is associated with earlyonset preeclampsia; A family history of chronic hypertension is associated with late onset preeclampsia. This may be explained by genetic predisposition [7].

\section{Markers}

Markers for predicting preeclampsia includes: Angiogenic Factors such as Vascular Endothelial Growth Factor (VEGF), Placental Growth Factor (PlGF), Fms-like Tyrosine Kinase (flt) -1 and Soluble Endoglin [10]; P-Selectin [11]; Cells Free fetal DNA [12]; ADAM12 (Disintegrin and Metalloprotease 12) [13]; Placental protein 13 [14; Pentraxin 3 [15]; PregnancyAssociated Plasma Protein A [16]; and Doppler Sonography of Uterine Artery [17].

\section{Maternal and Perinatal Outcome}

The ratio of maternal and perinatal mortality of near missed cases are $0.96 \%$ and $29.06 \%$. The ratio of cases in which maternal life at risk (maternal and maternal mortality near missed) is $30 \%$. Premature birth, intrauterine death between $20-28$ weeks, intrauterine death between 28-37 weeks, first trimester abortion aresignificantly higher in women with early onset preeclampsia compared to late onset. The incidence of disease histories other than chronic hypertension (especially diabetes mellitus), the history of preterm delivery is significantly higher in women with late-onset preeclampsia. The mean gestational age at delivery and birth weight are significantly lower in early-onset preeclampsia. The incidence of stillbirth, early neonatalmortality and late neonatal mortality, cases in which maternal life at risk are significantly higher in women with early onset preeclampsia [9].

\section{Prognosis}

Stillbirth, early and late neonatal mortality, cases in which maternal life at risk were significantly higher in early-onset preeclampsia. Women with early onset preeclampsia have higher maternal mortality rates than late onset [9] Early onset preeclampsia also needs longer duration of treatment. Babies born from early-onset preeclampsia mothers particularly are troublesome. Infants commonly suffer asphyxia and lower birth weight, and those are rarely happened in late-onset preeclampsia. This implicates in lower survival rate of baby born from early onset preeclampsia. So it can be concluded that perinatal mortality and morbidity in early onset are way worse [18].

\section{References}

1. Osungbade KO, Ige OK (2011) Public Health Perspectives of Preeclampsia in Developing Countries: Implication for Health System Strengthening. Journal of Pregnancy 2011: 1-6.

2. Kooffreh ME, Ekott M, Ekpoudom DO (2014) The Prevalence of Preeclampsia Among Pregnant Women in The University of Calabar Teaching Hospital, Calabar. Saudi Journal for Health Sciences 3(3): 133-136.

3. Sulistyowati S, Soetrisno S, Kartika NH (2016) Ekspresi Human Leukocyte Antigen-C di Trofoblas dan Natural Killer Cell di Desidua pada Preeklampsia Berat. Jurnal Kedokteran Brawijaya 29(1): 59-63.

4. Huppertz B (2008) Placental origins of preeclampsia: challenging the current hypothesis. Hypertension 51(4): 970-975.

5. Lisonkova S, Sabr Y, Mayer C, Young C, Skoll A, et al. (2014) Maternal morbidity associated with early-onset and late-onset preeclampsia. Obstet Gynecol 124(4): 771-781.

6. Madazli R, Yuksel MA, Imamoglu M, Tuten A, Oncul M, et al. (2014) Comparison of clinical and perinatal outcomes in early- and late-onset preeclampsia. Arch Gynecol Obstet 290(1): 53-57.

7. Bhadarka N, Mukherjee TN (2016) Risk Factors of Early and Late Onset Pre-Eclampsia in Population Admitted at Gujarat Adani Institute of Medical Science, Bhuj, Kutch, Gujarat, India. International Journal of Current Research in Life Sciences 5(3): 569-572

8. Nanjundan P, Bagga R, Kalra JK, Thakur JS, Raveendran A (2011) Risk factors for early onset severe pre-eclampsia and eclampsia among north Indian women. J Obstet Gynaecol 31(5): 384-389.

9. Cheng $\mathrm{MH}$, Wang $\mathrm{PH}$ (2009) Placentation abnormalities in the pathophysiology of preeclampsia. Expert Rev Mol Diagn 9(1): 37-49.

10. Sulistyowati S, Roswendi A, Kartika H, Respati SH (2014) Kadar Soluble Human Leukocyte Antigen-G (sHLA-G), Vascular Endothelial Growth Factor (VEGF) dan Soluble Fms-Like Tyrosine Kinase-1 (sFlt-1) pada Preeklampsia. Majalah Obstetri \& Ginekologi 22(3): 126-131.

11. Chavarría ME, Lara-González L, García-Paleta Y, Vital-Reyes VS Reyes A (2008) Adhesion molecules changes at 20 gestation weeks in pregnancies complicated by preeclampsia. Eur J Obstet Gynecol Reprod Biol 137(2): 157-164.

12. Vodicka R, Vrtel R, Dusek L, Prochazka M, Schneiderova E, et al. (2008) Refined fluorescent STR quantification of cell-free fetal DNA during pregnancy in physiological and Down syndrome fetuses. Prenat Diagn 28(5): 425-433. 
13. Spencer K, Cowans NJ (2007) ADAM12 as a marker of trisomy 18 in the first and second trimester of pregnancy. J Matern Fetal Neonatal Med 20(9): 645-650

14. Sekizawa A, Purwosunu Y, Yoshimura S, Nakamura M, Shimizu H, et al. (2009) PP13 mRNA expression in trophoblasts from preeclamptic placentas. Reprod Sci 16(4): 408-413.

15. Popovici RM, Krause MS, Jauckus J, Germeyer A, Brum IS, et al. (2008) The long pentraxin PTX3 in human endometrium: regulation by steroids and trophoblast products. Endocrinology 149(3): 1136-1143.
16. Cowans NJ, Spencer K (2007) First-trimester ADAM12 and PAPP-A as markers for intrauterine fetal growth restriction through their roles in the insulin-like growth factor system. Prenat Diagn 27(3): 264-271.

17. Scifres CM, Nelson DM (2009) Intrauterine growth restriction, human placental development and trophoblast cell death. J Physiol 587(Pt 14): 3453-3458.

18. Pettit F, Mangos G, Davis G, Henry A, Brown MA (2015) Pre-eclampsia causes adverse maternal outcomes across the gestational spectrum. Pregnancy Hypertens 5(2): 198-204.

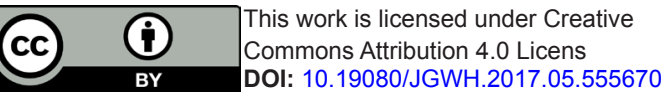

\section{Your next submission with Juniper Publishers will reach you the below assets}

- Quality Editorial service

- Swift Peer Review

- Reprints availability

- E-prints Service

- Manuscript Podcast for convenient understanding

- Global attainment for your research

- Manuscript accessibility in different formats ( Pdf, E-pub, Full Text, Audio)

- Unceasing customer service

Track the below URL for one-step submission https://juniperpublishers.com/online-submission.php 